\title{
Innovation and the Zone of Proximal Development in Engineering Education
}

\section{Mr. Nicholas D. Fila, Purdue University}

Nicholas D. Fila is a Ph.D. candidate in the School of Engineering Education at Purdue University. He earned a B.S. in Electrical Engineering and a M.S. in Electrical and Computer Engineering from the University of Illinois at Urbana-Champaign. His current research interests include innovation, empathy, and engineering design.

\section{Mr. Todd Mathew Fernandez, Purdue University, West Lafayette}

Todd is a PhD Student in Engineering Education at Purdue University who's research is focused on entrepreneurship education and entrepreneurship education as a component of modern engineering education efforts.

\section{Dr. Senay Purzer, Purdue University, West Lafayette}

enay Purzer is an Associate Professor in the School of Engineering Education. Her research examines how engineering students approach innovation. She also studies informed design practices among college and pre-college students . She serves on the editorial boards of Science Education and the Journal of Pre-College Engineering Education (JPEER).

\section{Mr. Austin Spencer Bohlin, Purdue University, West Lafayette}

I am a freshman in engineering at Purdue University. I am currently working as an undergraduate research assistant for the Engineering Education department through INSPIRE. 


\title{
Innovation and the Zone of Proximal Development in Engineering Education
}

\begin{abstract}
Recent scholarship has emphasized incorporating innovation experiences into engineering curricula. These experiences are often positive, especially when students have the opportunity to solve novel but challenging problems, navigate their own processes, critically reflect on their experiences, and receive appropriate levels of support and scaffolding. This study further explores the role of scaffolding on innovation and non-innovative projects through the lens of Vygotsky's theory of proximal development. Ten engineering seniors participated in semistructured interviews focusing on their experiences with innovative and non-innovative projects and their general perspectives related to innovation. We utilized a qualitative content analysis approach to identify students' experiences within and outside of Vygotsky's zone of proximal development during innovation projects to which students felt they did and did not substantially contribute and non-innovative projects. Analysis revealed distinct characterizations aligned with experiences preceding, within, beyond their zones of proximal development on the three project types. These findings have key implications for those learning to become innovative and the way educators utilize innovation projects in the context of engineering education. In particular, they demonstrate strong connections between tasks in the zone of proximal development, how students develop technical and professional competencies during innovation projects, and how instructors may structure their projects to improve learning and innovation outcomes by establishing support practices from a variety of individuals.
\end{abstract}

\section{Introduction}

Innovation projects have become an increasingly important part of the engineering education landscape. Educators, responding to the call for more innovative engineers ${ }^{1-3}$ have implemented a variety of projects dedicated to helping their students develop the competencies to design and develop novel, viable, and change-making artifacts. While innovation projects have been explored in terms of the conditions under which students produce artifacts judged to be innovative $e^{4-6}$, less has been explored regarding the mechanisms that underlie student learning in these situations ${ }^{7}$.

In this paper, we investigate engineering students' descriptions of innovation projects through the lens of Vygotsky's ${ }^{8}$ zone of proximal development social theory. More specifically, we explore the operation of the zone of proximal development in projects students describe as noninnovative, innovative in aspects to which they directly contributed, and innovative in ways in which they did not directly contribute. This potential connection was identified in a previous study we conducted ${ }^{7}$ and is clarified in this paper. The research question that guided this investigation was: 
In what ways do student descriptions of engineering projects as being noninnovative, innovative with their contributions, and innovative without their contributions align with their learning in the zone of proximal development?

\section{Literature Review}

Innovation is a complex phenomenon that takes different forms in different contexts. Often, innovation is judged in terms of characteristics of a design solution. From a sociological perspective, innovation can be determined by the level at which a community or group adopts the solution $^{9}$. From a psychological perspective, an innovation is something novel and useful ${ }^{10}$. In new product development, an innovation can be thought of something that opens a new market ${ }^{11}$ or creates value for customers ${ }^{12}$. In engineering, innovations are often viewed in terms of three characteristics of the solution: (1) it is different than prior solutions, (2) it is valued by a group, and (3) it is implemented ${ }^{13}$.

The above definitions provide a baseline for investigations surrounding what innovation is, but offer little insight into the inner workings of student innovation projects. Preliminary investigations reveal that students may differ from instructors in the way they characterize the goals of, experience of, and competencies necessary to complete innovation projects ${ }^{7,14}$. These investigations suggests that above all else, engineering students view innovation as a joint opportunity to learn new innovation and technical competencies while also contributing to engineering innovations as defined by Ferguson and colleagues ${ }^{13}$. These experiences feature key elements of authenticity, autonomy, support, personal interest, and unfamiliarity. Some recent research suggests that at least some of these elements have supported innovative student outcomes ${ }^{6}$.

In the context of engineering, innovation has also been given a mystique of the unattainable among students. Several studies suggest that students view innovation, and the related concept of creativity, as external to engineering ${ }^{15,16}$ or an elusive skill that most individuals do not and will not possess ${ }^{14}$. These suppositions are often confirmed by evaluations of student work that suggest limited solution innovativeness ${ }^{4,17,18}$. Among students who have experienced innovation projects, this mystique vanishes. While students still view engineering innovation as challenging, these challenges are mitigated the support they receive from peers and supervisors ${ }^{7}$. Under these conditions, innovation becomes an opportunity to learn both innovation-related, technical, and social competencies.

\section{Theoretical Framework}

Innovation is a social endeavor. This is especially the case in a learning environment built on diverse support networks. In this study, we adopt Vygotsky's ${ }^{19}$ theorization of a zone of proximal development (ZPD) as a theoretical framework to understand how students relate their knowledge and abilities to innovative and non-innovative projects. The ZPD concept specifically focuses on the intersection of a person's learning and social or external influences that contribute to that learning through peers, instructors, and other forms of ability scaffolding. 
The ZPD concept divides tasks or activities into three categories: those that a student can perform without assistance, those that a student can perform with assistance, and those that a student cannot perform even with assistance ${ }^{20}$. A student's ZPD refers to the capacity to develop new capabilities in a specific area and does not refer to some specific capacity for innovation. New abilities are a product of developments that occur when a student acts outside of those tasks which they can perform unaided. The student is aided in this development by social interaction and the assistance of others, although that assistance is not required to come from an instructor or person of authority. Instead, assistance can come from any collaboration that contributes to the development of new knowledge or perspectives.

Rather than understanding collaboration as "a joint, coordinated effort to move forward, where the more expert partner is always providing support" (p. 11) ${ }^{20}$, Chaiklin proposes collaboration as any interaction that occurs for the purpose of completing a task. That interaction may be with an instructor, intentionally designed scaffolding, a support structure, or a peer ${ }^{21}$. All equally satisfy the with assistance provision of the zone of proximal development ${ }^{20}$.

For this study, the specific framework considers three locations of a student in relation to their ZPD: (1) The zone of no development, tasks which a student can do unaided and without collaboration; (2) the zone of proximal development, tasks which students can do with collaborative assistance described above; and (3) a zone beyond what students are able to develop or contribute, even with collaboration or assistance. We pair the ZPD dimension with a second dimension: Students' conceptions of their contribution to innovation. Here we identify the overarching project type during which an event/task preceding, within, or beyond one's ZPD occurs. These project types included: (1) Non-innovative projects, (2) projects that are innovative in aspects to which the student felt he or she directly contributed, and (3) projects that were innovative although the student did not feel he or she contributed to any innovative components. Understanding whether students identify the intersection of development and innovation builds on prior work by Fila, Purzer, and Mathis ${ }^{22}$ to explore students' self-imposed boundaries on their innovative action.

\section{Methods}

We utilized a qualitative content analysis approach to identify and describe tasks preceding, within, and beyond engineering students' zones of proximal development that they experienced during non-innovative projects as well as innovation projects to which they felt they did and did not substantially contribute. The following sections detail participant selection, data collection, our analytical perspective, and data analysis.

\section{Participants}

Ten senior undergraduate engineering students at a public university participated in this study. These students were purposefully selected from a sample of 25 students to maximize variation in gender, engineering major, and the type of innovation projects they have experienced (See Table 1). The decision to pursue purposeful sampling derived from prior work that shows disciplinary and gender differences in how students approach innovation ${ }^{22}$. As fourth-year students, all 
participants had contributed to a variety of curricular, co-curricular, and personal engineering projects, and thus were able to select from several non-innovative and innovation projects to discuss.

Table 1. Participant information

\begin{tabular}{llll}
\hline Pseudonym & Gender & Engineering Major & Innovation Projects Discussed \\
\hline Abby & Female & Agricultural & Service Learning (multiple) \\
Bobby & Male & Civil & $\begin{array}{l}\text { Service Learning } \\
\text { Course Project }\end{array}$ \\
Christine & Female & Civil & $\begin{array}{l}\text { Service Learning } \\
\text { Design competition }\end{array}$ \\
Dolores & Female & Chemical & Course Project \\
Edward & Male & Aeronautical \& & Design Competition \\
Fred & Male & Multidisciplinary & Industry Internship \\
Ginnie & Female & Biological & Course Project \\
Ivan & Male & Industrial & Course Project (multiple) \\
James & Male & Mechanical & Service Learning \\
Linda & Female & Industrial & Industry Internship \\
\hline
\end{tabular}

\section{Data Collection}

The primary data source in this study was a one-on-one interview between each participant and one of the authors. For consistency, the interviewing author was the same for each of the interviews. These interviews each lasted about one hour and focused on one or two innovation projects and at least one non-innovative project the students had experienced. The interviews did not rely on a predefined interpretation of an innovation project or non-innovative project.

Instead, students determined the projects they felt were innovative or not and described their reasons for selecting each project. Typically, students described innovation projects as those that led to a tangible deliverable that demonstrated some degree of novelty. They further differentiated these projects by describing whether they did or did not play a substantial role in the development of the innovative solution. Students contrasted their innovation projects from non-innovative projects, which they described as "routine" and "overly specified," and which did not result in novel deliverables.

The interviews were semi-structured, allowing the interviewer to revise question order, rephrase questions, and ask follow-up questions when appropriate. First, students described an innovation project. The interviewer then asked follow up questions to understand why students considered the project innovative, background about the project and their involvement, the approach they 
took, and personal experiences and reflections. The discussion of an individual project was complete when the interviewer had exhausted the possible content areas and when the participant could provide no new details or strands of inquiry. The interviewer and student then discussed at least one non-innovative project for contrast, and an additional innovation project if time permitted. Interviews were video- and audio-recorded and transcribed.

\section{Analytical perspective}

Our analysis attempted to respect both the socially constructed perspectives of the student participants as well as the theoretical framework which draws from well established theories of individual development and developmental potential. Following in constructivist traditions ${ }^{23}$, we held students' descriptions of their experiences to be representative of how they had experienced the phenomena of innovation and development. For example, we accepted students' explanations of projects as innovative or not innovative to be accurate conceptions of their perspectives on their experiences. However, we also compared students' descriptions of the innovative nature of projects, as well as their descriptions of their development, with baselines from the research team's experience.

This effort to explore gaps between the students experiencing the phenomena of innovation and development with the characteristics of innovation and the zone of proximal development are illuminated further in the Results and Discussion section below. Our reasoning for pursuing this path is perhaps best explained through an example. A participant might identify themselves as incapable of innovation because of a lack of technical ability (coded beyond zone of proximal development and innovation to which the student did not contribute), only to see the development of further technical ability recursively place innovative ideas or projects back in the non-innovative zone of no development. In such cases, while we respect student explanations as their authentic perspective, it is necessary for us as researchers to identify more subtle or nonobvious cues from a more positivist viewpoint on the innovation and developmental phenomena that students are describing.

\section{Data Analysis}

We used content analysis to code written transcripts of the student interviews. We began with a codebook based the theoretical framework. This codebook contained two dimensions and three codes within each dimension. The first dimension referred to a task the student described completing and its relation to the ZPD. The three codes in this dimension included: ZND (zone of no development - a task a student can complete without assistance), ZPD (zone of proximal development - a task a student can complete with the help of a more knowledgeable other), and BOL (beyond outer limits - a task a student cannot complete even with the help of a more knowledgeable other). The second dimension referred to the project type in which the student experienced a particular task. The three codes in this dimension included: non-innovative project, innovative project to which the student contributed, and innovative project to which the student did not contribute. Coders assigned each coded excerpt both a primary code, along the task dimension, as well as a secondary code, along the project dimension. 
Two of the authors coded based on the initial code book. One author coded all ten participant transcripts. A second author coded half of the transcripts for comparison, discussion, and interrater reliability purposes. A common threshold for overlap is $10-30 \%{ }^{24}$, so $50 \%$ was considered more than sufficient. After completing initial coding, authors met several times to rectify and align coding. We framed the meetings using the analytical perspective described above by ensuring coding was grounded in both the theoretical framework and the participants' experiences. This process involved discussion between both coders and a third author. In these discussions, both coding authors explained the logic of their coding choices and the three authors agreed on the appropriate code. After each meeting, we refined the codebook to account for discrepancies discussed during the meeting and to add additional clarification when appropriate.

During a final meeting, we computed Cohen's $\kappa$ as a measure of inter-rater reliability for codes in both code dimensions. These values (.76 for task location in relation to $Z P D$ and .82 for project type) were sufficient to demonstrate strong inter-rater reliability ${ }^{25}$. We reconciled all remaining instances in which the two coders disagreed and revised the codebook a final time (see Table 2). The two authors coded a final time based on this code book and agreed on all codes.

Table 2. Description of primary and secondary codes

\begin{tabular}{|c|l|l|}
\hline $\begin{array}{c}\text { Code } \\
\text { Dimension }\end{array}$ & \multicolumn{1}{|c|}{ Code } & \multicolumn{1}{|c|}{ Description } \\
\hline \multirow{5}{*}{$\begin{array}{c}\text { Task location } \\
\text { in relation to } \\
\text { ZPD }\end{array}$} & Zone of no development & $\begin{array}{l}\text { A task that does not require the participant to develop, refine, or } \\
\text { expand competencies } \\
\text { What the student can do by themselves }\end{array}$ \\
\cline { 2 - 3 } & Zone of proximal development & $\begin{array}{l}\text { A task requires the development or expansion of competencies that } \\
\text { participants can perform at a given point in time } \\
\text { What the participant can do in collaboration } \text { with someone else } \\
\text { (e.g., peer, instructor, mentor) }\end{array}$ \\
\cline { 2 - 4 } & $\begin{array}{l}\text { Beyond zone of proximal } \\
\text { development }\end{array}$ & $\begin{array}{l}\text { A task requiring competencies that the participants do not have } \\
\text { and cannot develop within that context } \\
\text { What the participant cannot do even through collaboration with or } \\
\text { assistance of others }\end{array}$ \\
\hline \multirow{5}{*}{\begin{tabular}{l} 
Project type \\
\cline { 2 - 3 }
\end{tabular}} & $\begin{array}{l}\text { Non-innovative project } \\
\text { (to which the student } \\
\text { contributed) }\end{array}$ & $\begin{array}{l}\text { A project involving the use of solutions or answers that already } \\
\text { exist. } \\
\text { Projects which do not require students to utilize novel design or } \\
\text { problem solving processes. }\end{array}$ \\
\cline { 2 - 3 } & $\begin{array}{l}\text { Innovative project } \\
\text { (to which the student did not } \\
\text { contribute) }\end{array}$ & $\begin{array}{l}\text { A project involving the development of a novel and tangible } \\
\text { solution to an unmet need. } \\
\text { Student played a role in developing novel components of the } \\
\text { solution, often requiring them to utilize novel problem solving } \\
\text { processes. }\end{array}$ \\
\hline $\begin{array}{l}\text { A project involving the development of a novel and tangible } \\
\text { solution to an unmet need. } \\
\text { Student did not actively contribute to the project or did not } \\
\text { contribute to the novel components of the project. }\end{array}$ \\
\hline
\end{tabular}




\section{Results and Discussion}

Data analysis revealed multiple instances of each code. Moreover, we found evidence of seven of the nine possible code pairs (i.e., types of tasks (ZND, ZPD, or BZPD) in each project type). The two code pairs we did not observe were: (1) tasks beyond the zone of proximal develop in noninnovative projects and (2) tasks in the zone of proximal development in innovation projects to which the student did not contribute. We detail how students described ZND, ZPD, and BZPD tasks (when applicable) across all three project types in the sections below.

\section{Non-Innovative Projects}

Students described non-innovative projects as "routine" and "boring." These projects were often course projects such as lab exercises and technical design projects. They were marked by fixed procedures given by instructors or supervisors and the knowledge that there would be one or a limited set of correct answers. Due to these constraints, students felt limited in their opportunity to innovate and often felt there was little opportunity to learn. The experiences instead served to evaluate their abilities or demonstrate a particular phenomenon/topic. As a result, these experiences often fell into the zone of no development. For example, Frank described an EPICS project that was well within his abilities.

I had already seen different software that did it. I mean ... because it wasn't really anything new... Just the fact that it pretty much had been done before and like it wasn't necessarily something new really, didn't make it feel as innovative to me... our real goal was we had the finished project and we had to deploy it onto a server. That was really all we had to do. There wasn't too much real work to do. (Frank, Multidisciplinary Engineering)

In a single alternative example, Edward described a non-innovative project with elements that fit within the zone of proximal development. This project had many markings of innovative projects, such as autonomy, authenticity, and unfamiliarity ${ }^{7}$, but resulted in a non-innovative solution. Edward indicated that he and his team lacked the technical knowledge to be innovative on the project. Still, through instructor scaffolding on this non-innovative project, Edward began to develop the technical knowledge that he believed could support innovation on later projects.

Our actual task was to go a certain range with a certain amount of mass and that's really all that they told you. Cargo planes have existed for a very long time, so if you go through all the "designs" [air quotes] our course came up with, you had someone who essentially redesigned the C7, someone who essentially redesigned the C130, someone who essentially redesigned a Ukrainian Antinov... Without having that much technical background in aerospace, you can't just be like, "Well we're gonna do this which will make this better which is this brand new, innovative design in cargo aircraft." (Edward, Aeronautical Engineering)

As noted, we did not identify any examples of non-innovative projects that involved tasks beyond the students' ZPDs. Tasks beyond the ZPD are beyond what the student can achieve or contribute to even with assistance ${ }^{20}$. Given that the majority of non-innovative projects that 
students described were aimed at specific technical learning objectives (i.e., course assignments), creating projects outside of the scope of student ability would seem inappropriate. Alternatively, such tasks may appear much like the BZPD tasks on innovative projects: those that are outsourced or delegated to others. One potential example of such a task would be an instructor providing a portion of base code for a routine programming assignment. The instructor might provide the code because it is likely to be too difficult for her/his students based on their current expertise, but the assignment might still not support student innovation. For example, students might feel constrained by the initial code, or may not feel the assignment allows for innovation based on their current capabilities.

\section{Innovative Projects to Which the Students Contributed}

Students described innovation projects to which they contributed as initially "overwhelming" and "intimidating" but eventually as "fun" and "exciting." In these projects, students felt that their efforts actively contributed to the innovative components of the project, whether the tasks fell into the zone of no development or the zone of proximal development. These projects existed as course projects, co-curricular projects such as internships and service learning projects, and occasionally, as personal projects. As described by Fila, Purzer, \& Fernandez, these projects were marked by authenticity, autonomy, support, personal interest, and unfamiliarity to the students.

The key (i.e., innovative) aspects of their work often fell into the zone of proximal development. During these experiences, students worked towards challenging tasks, which they did not initially have the ability or confidence to complete without scaffolding or assistance. While instructor scaffolding (to mitigate project complexity) often supported student learning and managed the challenge, students more frequently and emphatically reported support from their teammates and peers as an important factor. In some cases, team support involved distributing the cognitive load of the task (e.g., through team brainstorming). In other cases, new perspectives and actions evidenced by their teammates caused students to actively reflect and view the situation in a new light. As an example, Ivan (an industrial engineer) described how electrical engineering students assisted him in achieving a new understanding of the project technology, which aided innovation.

Everything in this project was something that none of us had done before, regardless of major or experience. Another thing that was innovative was all of us got to work with each other at some level. I worked with EE's and I learned from them how they design solar panel arrangements and how they use some of their power generation formulas and how they store energy in some of their battery systems. And I got to work with someone on the materials side, as to say "Okay. How do you work with this beam?" ... So, just learning small bits from everybody and just taking up tasks which none of us had ever done before. I think that was a really innovative part of the entire project for me. (Ivan, Industrial Engineering)

Students also experienced activities outside of the zone of proximal development during innovation projects, both in the zone of no development and beyond the zone of proximal development. Aligned with the zone of no development, innovative projects still required 
students to complete some tasks that they could do without assistance. Students' often described such tasks as the 'menial' or 'boring' components of innovation projects. This included elements such as programming, setting up experiments, and drafting reports that were necessary in service to the team's innovation. For example, Christine discussed the task of coding during an innovation project.

Sitting down and actually like coding stuff out, and going through all of the little errors that happened. Yeah, just forgetting a semicolon here or there at the end of a line and trying to find every one. (Christine, Civil Engineering)

Conversely, students also experienced tasks beyond their zones of proximal development during their innovation projects. In these instances, they contributed to a component of the innovation, but needed others to complete components that were beyond their abilities. Often, this included delegating work to more experienced teammates or outsourcing technology development to external organizations. The students typically used language indicating adoption rather than development (i.e., 'borrowing') in these cases. For example, Bobby described partnering with a larger organization who developed the water filtration technology that was a key technological element of his team's innovative community water system.

So we borrowed some technologies from them and it's using micro filtration, some sort of hollow fiber filtration where it cleans water by passing the water through pores in submicron levels, which are so small that even bacteria and parasitic life can't even pass through it. It's too small for that, but obviously water can still get through. And the issue with that system, though, is that since they're submicron sized pores you're very prone to clogging, like extremely quickly... So by preceding the hollow fiber membrane system-the hull fiber membrane filter with a sand filter we're increasing the water quality by reducing viral activity and bacterial activity and we're increasing the life of the membrane filter because it's filtering less particulate... Where the innovation comes in is that the reason why water projects fail a lot of times is because you develop a system, you leave it to the people and you come back in ten years and it's not operational, it's broken, it's not doing its job correctly, it' not filtering the water. For whatever reason it's not operating as the design intended. And to prevent the deterioration of our system, if you're doing community scale is um we're placing it in a school and the way the school operates in that community is the cafeteria is run by an outside organization which is actually parents. (Bobby, Civil Engineering)

This outsourcing, borrowing, or partnering, while representing tasks currently outside the students' zones of proximal development, may support future development by providing a baseline of knowledge in the technological area (e.g., understanding the terminology). Such knowledge may place such experiences within the students' zones of proximal development during future encounters, but further exploration of this phenomenon is needed.

\section{Innovative Projects to Which Students Did Not Contribute}

Students also shared first-hand experiences on projects that resulted in innovation, but to which the they felt they provided a limited contribution. These were often large-scale innovations and 
featured students observing or working under experienced engineers and were typically outside of engineering classes. As a result of these circumstances, students often had limited opportunities, either by their role or knowledge, to perform tasks they deemed as critical to the innovation.

A portion of these experiences fell into the zone of no development. Students were given simple tasks in service of a larger innovation project. For example, Christine described routine and prescribed work drafting CAD models while Ivan described using financial algorithms to find answers his supervisor requested. While these experiences could be compared to zone of no development experiences within innovation projects to which the students contributed, a key difference is that the students felt little connection to the innovation components of the project. As Dolores described, this was often because the guiding idea for the innovation was not their own.

I worked on one project. We were working on something that was fairly different than what I've seen before, but it wasn't my idea. I was just helping them work on it ... it was someone else's innovative idea that we were trying to make feasible. (Dolores, Chemical Engineering)

The other portion of these experiences were interpreted by students as beyond their zones of proximal development. In these examples, students were excited to observe innovative professional engineers in action, but their role was self-described as observational. They viewed the task as so far beyond their expertise that they could only watch and support the engineers as appropriate. Edward, for example, described an example when working at NASA.

There was a spacewalk going on and they were changing out a box on the outside of the Space Station and they couldn't get the new one on. And they weren't sure why. So, obviously, all these high level meetings were going on and they figured out that there was something wrong with the stanchion post that this bolts into and that they have to clean it. But we only have so many things on the Space Station to clean this thing with and there's no tool that's built to clean, uh, bolt threads. So they basically had an Apollo 13 moment where they laid out every tool we had on the Space Station, inside and outside, and have at it. So people in my branch and the EVA branch were essentially working twenty four hour shifts for a weekend trying to figure out how to clean this thing. And that was pretty, pretty fun walking around Mission Control with toothbrushes and things like that to come up with a solution to clean this pipe... So I mean, that was an incredibly innovative solution when it was a pretty stressful time for them. (Edward, Aeronautical Engineering)

We did not observe any instances of tasks within a student's ZPD on these innovation projects to which they did not contribute. We would expect tasks here to be ones that a students can complete with support but do not contribute directly to innovation, which would seem to be paradoxical. ZPD tasks in both other project types often involved developing non-obvious ideas or solutions in the context both other project types. Such non-obvious solutions would seem to give students a feeling of contributing to innovation. Thus, a student working on an innovation 
project to which they to do feel they have contributed, would likely shift to believing they contributed once they experienced a task within their ZPD.

\section{Developmental Innovation Matrix}

In summarizing the above results, we created the Developmental Innovation Matrix. This matrix (presented as Table 3) describes the types of activities during non-innovative projects, innovative projects to which students contributed, and innovation projects to which students did not contribute that fell within the zone of no development, zone of proximal develop, and beyond the zone of proximal development. This table serves two purposes. First, it describes elements instructors might expect students to experience on different project types. Second, it provides potential nuances in the projects (or how students view those projects) that could affect how students experience those projects.

Table 3. Developmental Innovation Matrix

\begin{tabular}{|c|c|c|c|}
\hline & Non-innovative project & $\begin{array}{l}\text { Innovative project } \\
\text { (to which the student } \\
\text { contributed) }\end{array}$ & $\begin{array}{l}\text { Innovative project } \\
\text { (to which the student did not } \\
\text { contribute) }\end{array}$ \\
\hline \multirow{2}{*}{$\begin{array}{l}\text { Zone of no } \\
\text { development }\end{array}$} & Box 1 & Box 2 & Box 3 \\
\hline & $\begin{array}{l}\text { Routine or overly specified } \\
\text { tasks in a self-contained } \\
\text { project (e.g., cookbook } \\
\text { laboratory exercises) }\end{array}$ & $\begin{array}{l}\text { Routine tasks in the context of } \\
\text { a student-led innovation } \\
\text { project (e.g., project } \\
\text { organization, documentation, } \\
\text { basic programming tasks) }\end{array}$ & $\begin{array}{l}\text { Routine or overly specified } \\
\text { tasks in support of another's } \\
\text { innovation project (e.g., } \\
\text { completing a CAD drawing } \\
\text { per another engineer's } \\
\text { specifications) }\end{array}$ \\
\hline \multirow{2}{*}{$\begin{array}{l}\text { Zone of } \\
\text { proximal } \\
\text { development }\end{array}$} & Box 4 & Box 5 & Box 6 \\
\hline & $\begin{array}{l}\text { Open-ended tasks beyond } \\
\text { students' current capabilities } \\
\text { (e.g., challenging technical } \\
\text { design tasks with several } \\
\text { existing solutions) }\end{array}$ & $\begin{array}{l}\text { Completing challenging tasks } \\
\text { with the support of others on a } \\
\text { student-led innovation project } \\
\text { (e.g., iteratively learning about } \\
\text { and designing a solar panel } \\
\text { array) }\end{array}$ & $\begin{array}{l}\text { Not observed (potentially } \\
\text { paradoxical) }\end{array}$ \\
\hline \multirow{2}{*}{$\begin{array}{l}\text { Beyond zone } \\
\text { of proximal } \\
\text { development }\end{array}$} & Box 7 & Box 8 & Box 9 \\
\hline & $\begin{array}{l}\text { Not observed (could } \\
\text { potentially be instructor- } \\
\text { provided code or design specs) }\end{array}$ & $\begin{array}{l}\text { Delegating or outsourcing } \\
\text { tasks beyond the students' } \\
\text { current capabilities in support } \\
\text { of a student-led innovation } \\
\text { project (e.g., receiving detailed } \\
\text { designs for project components } \\
\text { from third parties) }\end{array}$ & $\begin{array}{l}\text { Observing others complete } \\
\text { innovative work (e.g., } \\
\text { watching an experienced } \\
\text { engineer solve a challenging } \\
\text { problem) }\end{array}$ \\
\hline
\end{tabular}

Toward the first point, students' experiences on each of the three project types were rather consistent. Students described non-innovative projects as defined by routine or well-specified tasks or projects. Students perceived little challenge or room for innovative thought on such tasks. As a result, most of these experiences were classified in the zone of no development unless specifically organized to scaffold a particular ability development. Innovative projects to which 
students did not contribute were also marked by routine or overly specified tasks, but also tasks that were outside of the students' capabilities. Thus, while innovation occurred, students were either unable or not allowed to contribute. In both cases, students did not encounter significant challenges and were not operating in their zones of proximal development.

During innovation projects to which they contributed, students also encountered the routine tasks that marked the zone of no development and the overly challenging tasks that extended beyond their zones of proximal development. However, the more critical and noteworthy aspects of these projects fell between these two extremes and represented challenges students could complete and grow from through appropriate scaffolding and peer support. Thus, instructors hoping to create meaningful innovative project experiences for their students could use these project aspects (reasonable challenge and intentional support structures through instruction, mentorship, or peering) as guidelines.

Toward the second point, in comparing the differences between individual boxes, we can observe nuances in student mindsets and project features that have the potential to greatly influence student experiences. First, in exploring the manifestation of the zone of no development, we observe that it occurred during all three project types. While this was a defining feature of non-innovative projects and innovative projects to which students did not contribute, occurrences during innovative projects to which students contributed were viewed as necessary but unsubstantial. This result indicates that meaningful innovation experiences need not be entirely novel, creative, or challenging to students, and that students may tolerate or even enjoy these activities in service to larger goals in which they carry a stake. In many cases, students identify these tasks as authentic components of projects, which aligns with other studies of students' innovation perceptions ${ }^{7}$.

Second, boxes 4 and 9 (respectively, in the zone of proximal development on non-innovative projects and beyond the zone of proximal development on innovative projects to which students did not contribute) shared some similarities to box 5 (in the zone of proximal development on innovative projects to which students contributed). The box 4 example was similar to box 5 in all but the student's perception of whether the outcome was innovative. In other words, the result may have been considered innovative and the experience may have been considered more meaningful to other students. More work needs to be done to explore the reasons for and results of such a discrepancy. The box 9 example was also similar to box 5 in terms of the students' initial assessment of the situation. In both, students were initially intimidated by the project and viewed themselves as lacking the competence to contribute. However, in box 5 examples, students pushed past this initial apprehension and contributed to innovative outcomes. The difference may be a product of the students' mindsets, but may also have resulted from appropriate scaffolding and peer support that marks the zone of proximal development. Comparing similar examples can help clarify the distinction between these two types of experiences. Since this was an exploratory study with a limited number of students, the findings should be viewed carefully. Future research can explore and expand the framework proposed. 


\section{Conclusion}

Educators want engineering students to be innovative. Yet, for students to be innovative, they need scaffolding aligned with their current state of competencies. If projects that require or attempt to elicit innovation exist within what students can do unaided or outside what students can do with assistance, students' interaction with innovation decreases. The current body of literature on student innovation has been dualistic, meaning they examine whether or not students are innovative. Our study provides a new perspective on levels of innovative behavior associated with their zone of proximal development. The Developmental Innovation Matrix (DIM) provides a framework that can guide ways to improve scaffolding efforts in the projects students experience. In future studies, we will work to refine this framework and investigate its application in authentic instructional contexts.

\section{References}

1. Duderstadt, J. (2008). Engineering for a changing world. Ann Arbor, MI: The Millennium Project, University of Michigan.

2. National Academy of Engineering (NAE). (2004). The engineer of 2020: Visions of engineering in the new century, Washington, DC: The National Academies Press.

3. Radcliffe, D.F. Innovation as a meta attribute for graduate engineers. International Journal of Engineering Education 21, 194-199 (2005).

4. Fila, N. D., \& Purzer, Ş. (2014). The relationship between team gender diversity, idea variety, and potential for design innovation. International Journal of Engineering Education, 30(6A), 1405-1418.

5. Johnson, D. G., Genco, N., Saunders, M. N., Williams, P., Seepersad, C. C., \& Hölttä-Otto, K. (2014). An Experimental Investigation of the Effectiveness of Empathic Experience Design for Innovative Concept Generation. Journal of Mechanical Design, 136(5), 051009. http://doi.org/10.1115/1.4026951

6. Svihla, V., Petrosino, A. J., \& Diller, K. R. (2012). Learning to Design: Authenticity, Negotiation, and Innovation. International Journal of Engineering Education, 28(4), 782.

7. Fila, N. D., Purzer, Ş., \& Fernandez, T. M. (Under review). How engineering students characterize their innovative design experiences.

8. Vygotsky, L. S. (1978). Mind in Society: The development of Higher Psychological Processes. (M. Cole, V. John-Steiner, S. Scrbner, \& E. Souberman, Eds.). Cambridge, MA: Harvard University Press.

9. Rogers, E.M. (2003). Diffusion of innovations (5th ed.). New York, NY: Free Press.

10. Amabile, T. M., Conti, R., Coon, H., Lazenby, J. \& Herron, M. (1996). Assessing the Work Environment for Creativity, Academy of Management Journal, 39(5), 1154-1184.

11. Schumpeter, J. (1921). Capitalism, Socialism, and Democracy. Routledge.

12. Carlson, C. R., \& Wilmot, W. W. (2006). Innovation: The five disciplines for creating what customers want. New York: Crown Business.

13. Ferguson, D. M., Cawthorne, J. E., Ahn, B., \& Ohland, M. W. (2013). Engineering innovativeness. Journal of Engineering Entrepreneurship, 4(1), 1-16.

14. Zhang, F., Kolmos, A., \& De Graaf, E. (2013). Conceptualizations on innovation competency in a problemand project-based learning curriculum: From an activity theory perspective. International Journal of Engineering Education, 19(1), 3-16. 
15. Cropley, D. H. (2015). Promoting creativity and innovation in engineering education. Psychology of Aesthetics, Creativity, and the Arts, 9(2), 161-171. http://doi.org/10.1037/aca0000008

16. Kazerounian, K., \& Foley, S. (2007). Barriers to Creativity in Engineering Education: A Study of Instructors and Students Perceptions. Journal of Mechanical Design, 129(7), 761. http://doi.org/10.1115/1.2739569

17. Cropley, D. H., \& Cropley, A. J. (2000). Fostering creativity in engineering undergraduates. High ability studies, 11(2), 207-219.

18. Genco, N., Holtta-Otto, K. \& Seepersad, C.C. (2012). An experimental investigation of the innovation capabilities of undergraduate engineering students. Journal of Engineering Education, 101(1), 60-81.

19. Vygotsky, L. S. (1986). Thought and Language. (A. Kozulin, Ed.). Cambridge, MA: The MIT Press.

20. Chaiklin, S. (2003). The zone of proximal development in Vygotsky's analysis of learning and instruction. In A. Kozulin (Ed.), Vygotsky's educational theory and practice in cultural context (pp. 39-64). New York: Cambridge University Press. http://doi.org/10.1002/bit.

21. Holton, D. \& Clarke, D. (2006). Scaffolding and metacognition, International Journal of Mathematical Education in Science and Technology, 37(2), 127-143.

22. Fila, N. D., Purzer, Ş., \& Mathis, P. D. (2014). I'm not the creative type: Barriers to student creativity within engineering projects. Proceedings of the 2014 ASEE Annual Conference \& Exposition, Indianapolis, IN.

23. Atwater, M. M. (1996). Social constructivism: Infusion into the multicultural science education research agenda. Journal of Research in Science Teaching, 33(8), 821-837.

24. Patton, M. Q., (2002). Qualitative research and evaluation methods ( $3^{\text {rd }}$ ed.). Thousand Oaks, CA: Sage.

25. Landis, J. R. and Koch, G. G., (1977). The measurement of observer agreement for categorical data. Biometrics, 33(1), 159-174. 